\title{
The Better to See You With
}

\section{Peering into the Story of Little Red Riding Hood, $1695-1939$}

\section{ANGELA J.REYWOLDS}

I received the 2017 Bechtel Fellowship and spent a month in Gainesville, Florida, from mid-April through mid-May, trekking each day to the University of Florida. There I pored over hundreds of volumes containing the story of Little Red Riding Hood and spent my weekends compiling data or visiting wildlife parks in search of alligators (which were in abundance).

The story of Little Red Riding Hood has fascinated me since childhood, and now I am even more intrigued. Intense study of this story has led me to many fine explorations into the tale and has helped me understand the history of children's book publishing. The Bechtel Fellowship gave me the opportunity to learn a great deal about a specific story, and sharing this knowledge enables me to spread my love of story and children's books with others. Below is my report from my month of study.

$\mathrm{A}$ llow me to introduce you to a little girl. She can often be seen wearing a red hooded cape, blue aproned dress, and Mary Jane shoes. Sometimes she's wearing a red cap and wooden clogs. On occasion, she's in fancy dress, as though she's attending a party. She walks through the woods to visit her grandmother, who is not feeling well. She meets a wolf. You know how this story ends ... or do you?

Anyone familiar with children's literature has certainly read several versions of the Little Red Riding Hood story. But many do not know the history of this story, which has been around for at least three hundred years, likely more.

A Latin manuscript written in 1022 contains a poem in which a little girl in a red cloak is taken by a wolf, but the wolf cubs are unable to eat her because of her red cloak. ${ }^{1}$ Some folklorists say that this is not a Little Red Riding Hood story, but there are certainly elements of the familiar tale.

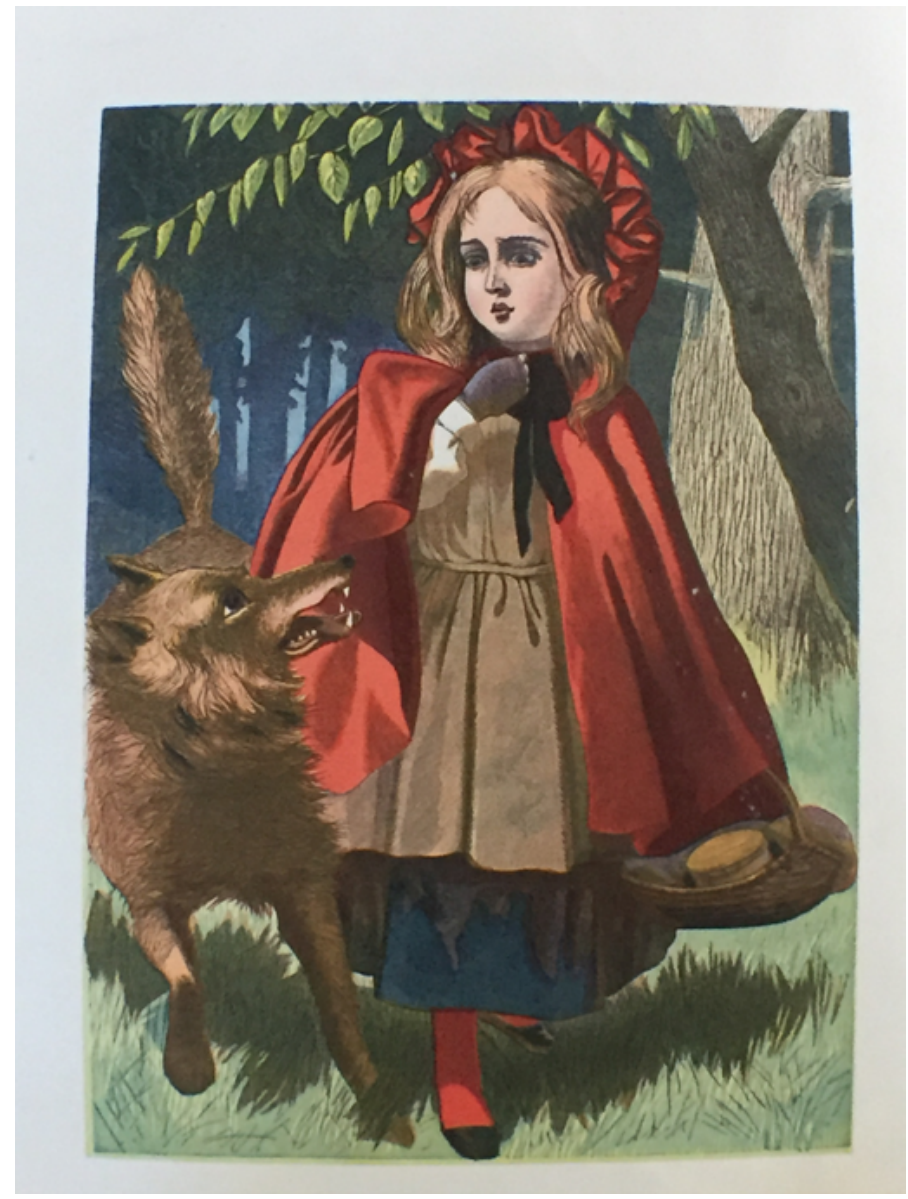

1864 illustration by Alfred Fredericks.

Charles Perrault's first published version of the tale, "Le petit chaperon rouge" (1697), is often regarded as the first time the story has been seen in print. And yet scholars agree that Perrault likely heard the folktale and fashioned it into a literary story both palatable and instructional to the French court (the story was crafted for adults, not children).

The tale that Perrault most likely heard is known as "The Grandmother's Tale," a gory version found in France and Italy in which the girl unknowingly eats her own grandmother (the wolf as Granny invites her to enjoy some meat and wine). In this version, the girl escapes the wolf.

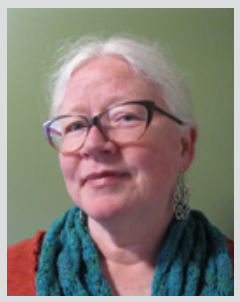

Angela J. Reynolds is the Community Engagement Coordinator for Annapolis Valley Regional Library in Nova Scotia, Canada. She served on the 2015 Caldecott Committee, has been reviewing children's books and audios since 1996, and spends much of her spare time reading. 
Skip forward to 1812 in Germany, when the Brothers Grimm first publish their version of the tale, "Little Red Cap." Also in the 1800s, French author Charles Marelles published a version of the story, "Little Golden Hood," elements of which sneak into the oeuvre of the tale.

Versions appear in Asia, often with the wolf as a tiger, though most folklorists believe that the tale did not originate in Asia; rather, they believe that the Asian versions are based on the European tale. It is interesting to note that in the Asian versions, as in "The Grandmother's Tale," the girl outwits the wolf and escapes.

The first published English version appears in 1729, translating the "petit chaperon rouge" into "Little Red Riding Hood." A red hooded cape was commonly worn as a riding or traveling cloak in rural England, and so this image easily hopped the channel from France to England. Until 1823, when the Grimm version was first translated into English, the Perrault version was the one known by English speakers and readers.

\section{Key Differences}

"Grandmother's Tale" elements: There is no mention of red hood or cap; the girl carries bread and milk to Grandmother; and Wolf asks if she will take path of needles or pins. Granny Wolf invites her to eat food (which is actually her grandmother); Granny Wolf says "undress and get in bed"; and the girl remarks, "Granny, how hairy you are." The girl has to pee (or poop); Wolf says do it in the bed, but the girl says no. The girl tells Granny Wolf to tie the rope around her leg so she can go outside, and the girl unties the rope and escapes. There is no moral.

Perrault elements: The little girl is the prettiest around; she gets no warning from Mother. She takes biscuits and pot of butter to Grandmother; Wolf says I'll take this path, you take that one, see who gets there first. Wolf doesn't want to eat her in the woods because a woodsman nearby might hear and kill him. The girl loiters; Grandmother dies; and at Grandmother's, Granny Wolf says "pull the bobbin" to come inside and tells the girl to get into bed. Little Red dies. The moral: young girls should be wary of — and not fooled by—wolves.

Grimm elements: The sweetest girl takes cake and bottle of wine to Grandmother; Mother warns her not to tarry or stray from the path. Wolf suggests she enjoy the walk; Little Red loiters, picking flowers. Granny says to "lift the latch"; Granny is eaten, Little Red is eaten; and Wolf snores. A hunter hears the snores, slits open Wolf's belly with a knife, and Granny and Little Red get out and fill the Wolf's belly with stones, and Wolf tries to get up but dies. (The original ends with an alternate story of Little Red learning her lesson and not being fooled next time.)

"Little Golden Hood" elements: The story is Grimm-based, but the "hood" is golden (fire colored). Granny is away, the

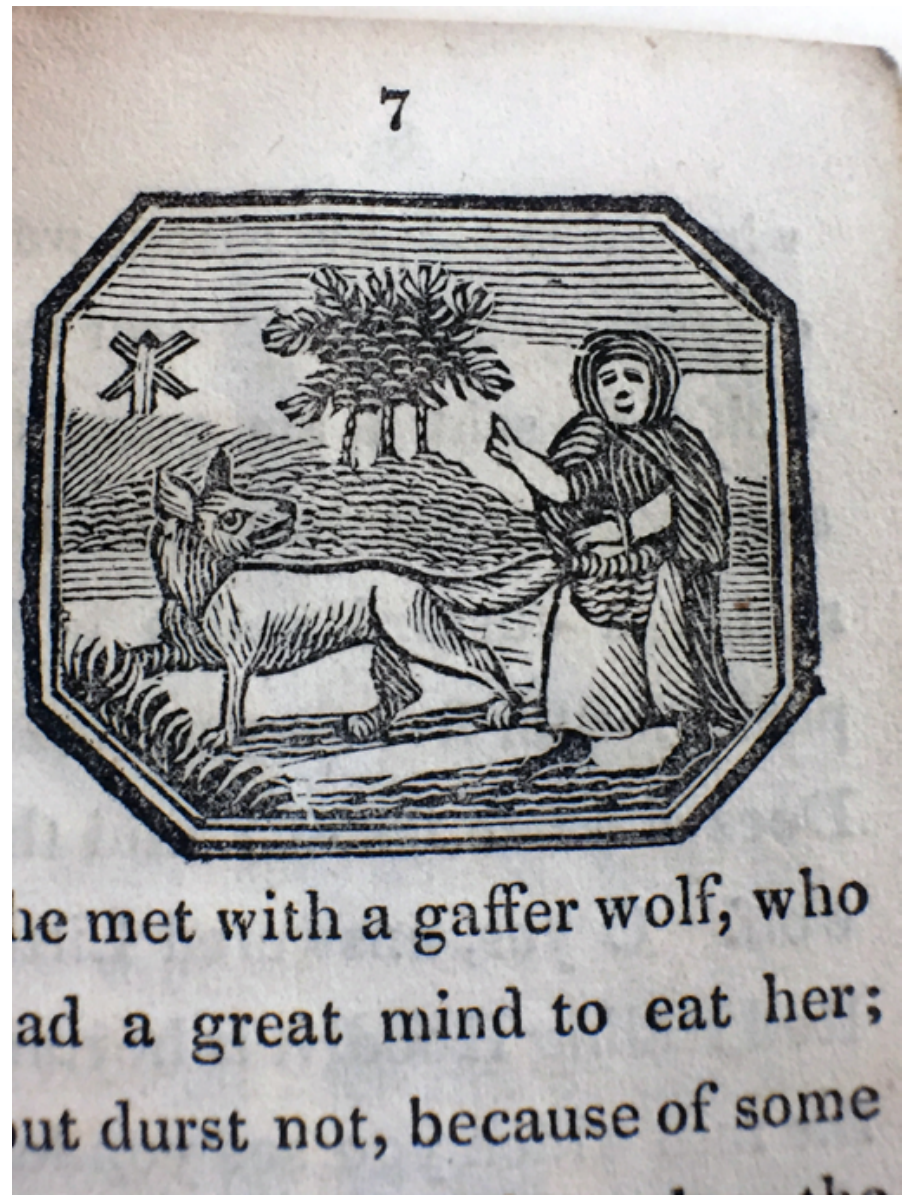

Early woodcut, with windmill in background (1820).

hood is magical and saves Little Red, and Granny catches and kills Wolf.

\section{By the Numbers}

While researching the Baldwin collection at the University of Florida, I looked at a little more than 200 individual books. This report is limited to those books published between 1695 and 1939. I refer to 158 individual books in this study. I chose 1939 as a stopping point for these reasons: there are many changes in publishing after World War II; however, I wanted to include some of the early 1900s books up through the 1930s to showcase the rapid changes in illustration during the early twentieth century. (The images can be seen in the accompanying slideshows; see "References" for links.)

In addition to the "standard" Perrault and Grimm versions, I uncovered at least 14 distinct story lines or "hybrid" versions in the books. The numbers below add up to larger than 158, as some stories shared story lines of several versions. The versions are charted in table 1.

The most common version is one in which Grandmother dies and stays dead, but Little Red is saved, often by a hunter, woodsman, or her father (50); next is the standard Perrault version (38) and then the standard Grimm version (12). 


\begin{tabular}{|c|c|c|}
\hline Version & Description & $\begin{array}{l}\text { Instances of } \\
\text { Version }\end{array}$ \\
\hline Perrault (standard) & see above & 38 \\
\hline Grimm (standard) & see above & 12 \\
\hline Hybrid 001 & Perrault Grimm Alt: Granny hides in closet, LITTLE RED saved, Wolf dies & 10 \\
\hline Hybrid 002 & Perrault Grimm saved: Granny dies, LITTLE RED is saved, Wolf dies & 50 \\
\hline Hybrid 003 & Grimm Wolf: Granny and LITTLE RED live, Wolf dies (no one eaten) & 1 \\
\hline Hybrid 004 & Perrault Grimm zoo: Granny and LITTLE RED live, Wolf taken to zoo & 3 \\
\hline Hybrid 005 & Original story with characters or plot lines from LITLE REDRH & 7 \\
\hline Hybrid 006 & Grimm alt: LITTLE RED and Granny removed, Wolf spared & 1 \\
\hline Hybrid 007 & Perrault Grimm Fairy: Granny dies, LITTLE RED saved, Wolf dies. LITLE RED meets 3 magical creatures & 8 \\
\hline Hybrid 008 & Perrault Grimm revenge: Granny and LITTLE RED eaten, Father or Woodsman kill Wolf for his cruelty & 6 \\
\hline Hybrid 009 & Perrault Grimm food: food is stolen while LITTLE RED wanders around loitering & 3 \\
\hline Hybrid 010 & Perrault Grimm Golden Hood: Granny is away; LITLE RED not eaten, Hunter kills Wolf & 7 \\
\hline Hybrid 011 & $\begin{array}{l}\text { Grimm hybrid: Granny runs away from Wolf, LITTLE RED escapes from Wolf, Woodsman and Granny } \\
\text { chase Wolf (no one dies). Similar to } 004\end{array}$ & 2 \\
\hline Hybrid 012 & Grimm alternate: Granny eaten, but later cut out. LITTLE RED saved by Woodsman, Wolf killed & 7 \\
\hline Hybrid 013 & Grimm alternates: Disney - both Little Red and Grandmother get in closet, saved by \#3 Pig. & 1 \\
\hline Hybrid 014 & Grimm variant: Everyone dies (Hunter shoots Wolf). May include second Grimm ending. & 5 \\
\hline
\end{tabular}

Coming in for a close fourth is a version influenced by Golden Hood, in which Granny hides in a closet, and Little Red is saved from the wolf.

Several versions make note that it was acceptable that the grandmother dies because she was old. A book published in 1906 in Chicago states, "but as she was a very good old woman, it was better for her to die than to live in pain."”

Some of the versions give us further information about wolves, who enjoy eating humans. A few versions end with the wolf being skinned to make a coat or rug for Little Red, to remind her of what has happened to poor Granny. Several save the Wolf, selling him off to a zoo or animal show, and one saves those proceeds in a trust for Little Red when she is older. One version ends in fire, another with the ghost of Little Red. One is set in Japan with an alligator in place of the Wolf. In addition to the hunter or woodsman, Little Red is sometimes saved by wasps, birds, cats, hunting dogs, or her grandmother.

The food carried by Little Red is typical, with some interesting additions or changes. In the Perrault version, she takes biscuits (galettes) and a pot of butter (though some translators give this as custard and butter); in Grimm, she takes cake and a bottle of wine (that same bottle of wine that caused trouble for the Trina Schart Hyman version in 1990). ${ }^{3}$ Very often, she sets off with cheesecakes, which were made as far back as the fourteenth century (a medieval recipe can be found that is quite similar to the cheesecakes we know today, only with much less sugar). ${ }^{4}$ Other food items include freshkilled chicken, honey, eggs, jelly or jam, apples, griddlecakes, gingerbread, pie, soup, tea, and, in a couple of original tales, chocolate, ice cream, and cream puffs.

As we can see, many variations of this story can be found. Textual differences may portray local or historical times (as in food), and plot lines often depict popular philosophies of the day, including the contemporary perceptions of children or the elderly. In the Perrault version, the lesson is this: little girls, do not be deceived by the wolf; your life will be over if you are. In Grimm, however, it is this: little girls, be obedient, stay on the path, and don't talk to strangers, but if you do disobey, there's a man waiting to save you.

"The Grandmother's Tale" (remember, this is likely the tale that Perrault drew from) shows the girl able to learn from her experience, perhaps consuming the wisdom of her grandmother (literally), and she escapes. The girl gains power and knowledge. In both Perrault and Grimm, and all the versions encountered up to 1940, the girl is helpless, eaten or saved, though she does begin to develop a bit of sense after World War I.

One may ask, What is this story really about? Some scholars and feminists believe it is a tale of rape: the girl encounters a stranger in the woods, gets in bed with this stranger, and is consequently devoured. Certainly, the Perrault moral warns of this very happenstance; yet, the legal definition of rape in Perrault's time pertains more to the "owner" of the girl (her father) than to the girl-a girl was her father's property until she was married, and damaged goods (i.e., nonvirginal) were of less value. This may sound harsh to our modern sensibilities, but this was the reality of seventeenth-century French aristocracy.

An interesting tidbit from this era is that when a girl lost her virginity, it was said that she had "seen the wolf." ${ }^{5}$ One may interpret this story as a girl willingly getting into bed with a "wolf," with Perrault delivering a moral statement warning young women not to do this. Indeed, the illustration of Perrault's original manuscript shows a girl unafraid of the wolf she is in bed with; in fact, she lovingly pets the wolf's face. 


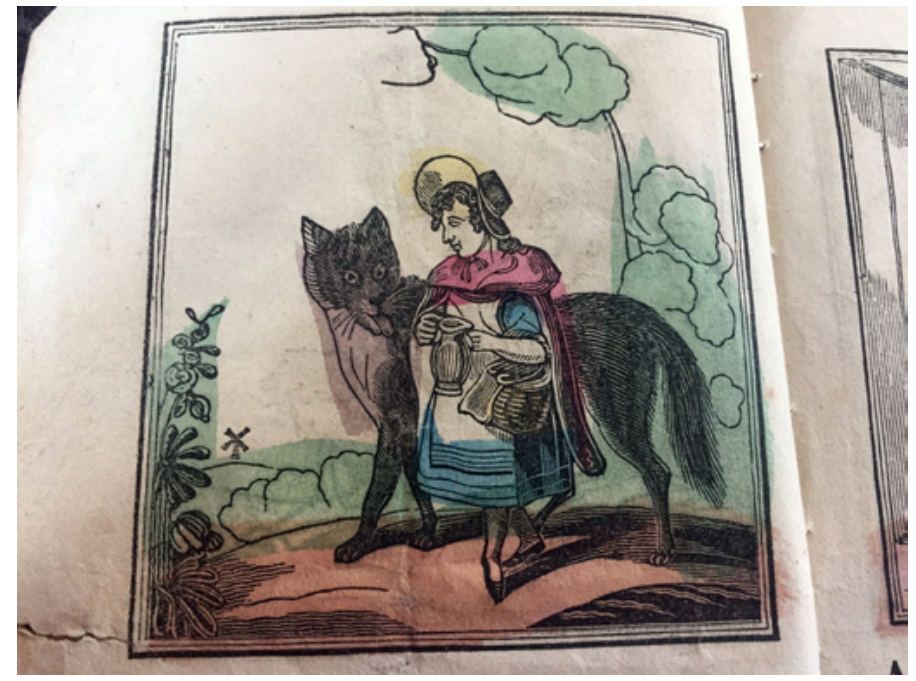

Hand-colored, adolescent girl in fancy bonnet (1840).

Other interpretations lean toward lessons of obedience; much of early children's literature contains a moralistic tone. The Grimm version does include the girl being devoured, but she is later saved. She disobeys her mother by dallying in the forest, picking flowers, thereby symbolizing a lazy child engaged in useless pursuits. Yet she is saved by a hunter, woodsman, or her father-a man to the rescue. Many of the illustrations of this version show the girl clinging to her savior. Both interpretations make sense for the time periods and contemporary modes of thought.

Another interpretation is the warning to children of being alone in the woods. The woods are dangerous for a young child alone (and in early European history, likely even more so). There were certainly wolves and other wild animals that could prey on a child. And then there are the werewolves. ${ }^{6}$

In 1590, there was a famous case of Stubbe Peter in Germany; a popular subject for broadsheets, this case became wellknown all over Europe. Earlier cases, such as those from 1340 and 1460 in Scotland, and perhaps even a few Norse instances, set the belief in werewolves firmly in the European mind.

In each case, a man has preyed on children, engaging in incest or cannibalizing them. The man was said to become a wolf at certain times, usually after making a pact with the devil or due to witchcraft. In many cases, the man confesses with a wild tale of transformation and a hunger to seek out young children to eat. These tales were taken seriously, and many a "werewolf" went to trial. In "The Grandmother's Tale," the wolf is named as bizou, which is sometimes translated as "werewolf."

\section{A Note on Illustrations}

In this study, I focus on two of the most common illustrations-meeting the wolf, and wolf as Granny. Many of the illustrated books also contain an illustration of Little Red and her mother, but not all do (especially not the Perrault versions,

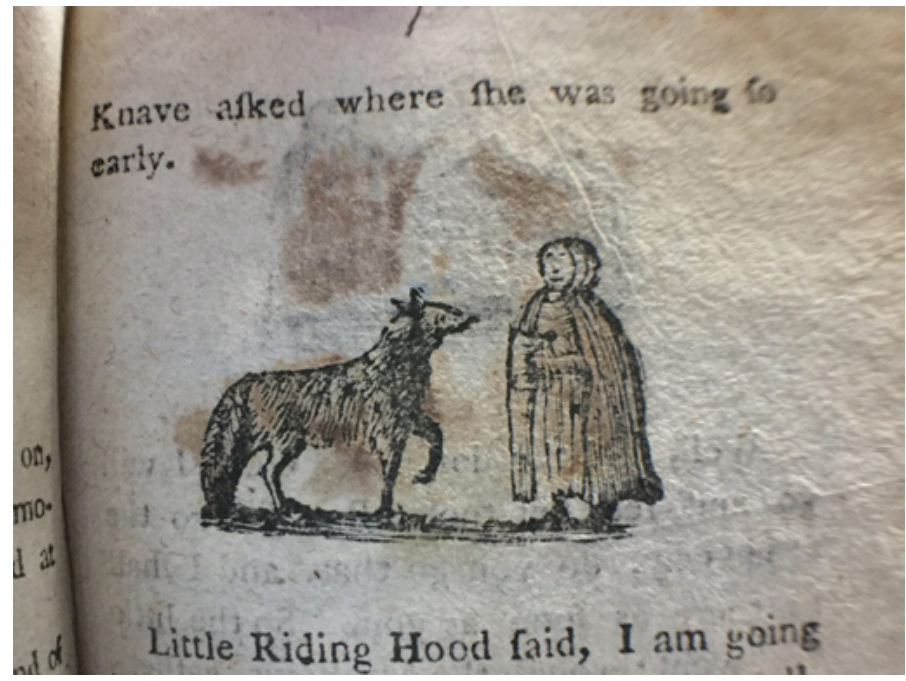

Early chapbook (1814).

which do not include a warning from Mother either); therefore, this study focuses on these two iconic images.

Nearly every illustrated Little Red Riding Hood tale will contain the image of the girl and the wolf in the woods. This is the most common image: if there is only one image in the story, it is most likely this one. Differences may be seen in how close the girl stands to the wolf, the size of the wolf compared to the girl, if the wolf is dressed in man's clothing, and the age of the girl. How far into the woods are they? Are the woods deep, with no sign of civilization? Are they at a crossroads? Are the woods dark and scary, or are there flowers, cheerful mushrooms, and bunnies?

Looking at the wolf, does his shadow overwhelm the girl? Is she afraid of him? Is his tongue out in a leering manner? Are his teeth showing? Do Little Red and the Wolf gaze at each other? And for Little Red, how is she dressed? How old is she (a young child or adolescent)? Does she carry a basket? What can we tell about her personality from the images?

In the Perrault story, the girl gets into bed with the wolf, and so we often see the image of Little Red in bed with Granny Wolf. In the Grimm versions, the image depicted is often Little Red standing at Granny's bedside. When the girl is in bed with the wolf, in the earlier illustrations we see the wolf looming above her, then later they sit next to one another under the covers.

In the bedside images, most common is the wolf as Granny with blankets pulled up, wearing Granny's night cap, with the girl standing at the foot or side of the bed. Often the bed is curtained, and the wolf may be turned away so that the girl cannot see him well. In later books, readers may see the wolf attacking the girl or the wolf being killed.

The history of children's literature can be traced through the tale of Little Red Riding Hood. From the "written for adults" Perrault manuscript of 1695, with an illustration of a 


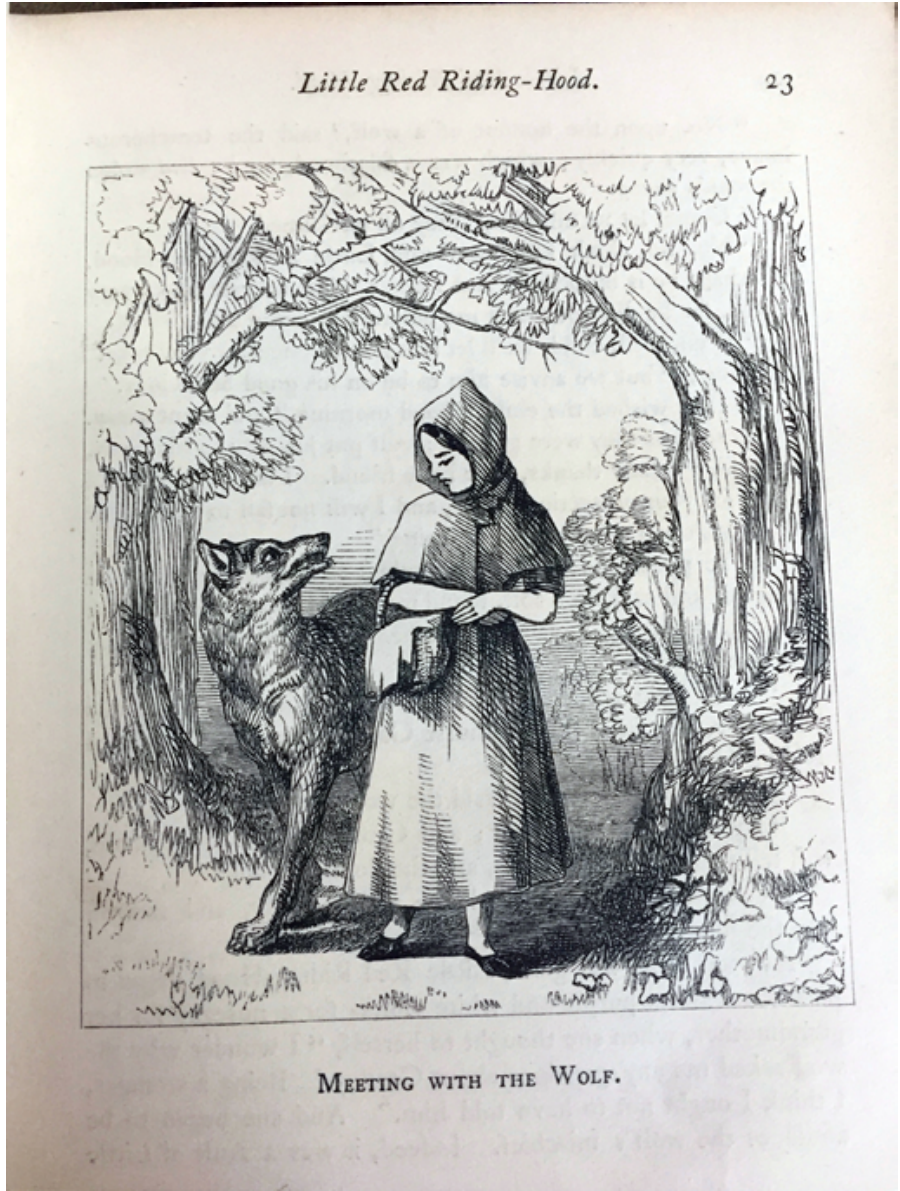

"The Gaze," 1885.

red-capped girl caressing the wolf in her curtained bed; the chapbooks with their rough woodcuts, featuring a large wolf and an ageless, nondescript girl in a hooded cape; the early engravings; and Gustave Doré's iconic, lush, seductive, and often imitated images; to Walter Crane's well-heeled manwolf, infantilized golden-haired cherubs of the 1890s, and the flapper-inspired, large-eyed Kewpie doll depictionsthroughout, we can see the history of book publishing, the changes in how Westerners view children, and the evolution of the tale.

In early woodcuts and chapbooks, the wolf is generally large, and the girl may appear to be an old woman or a very nondescript human. Early publications featuring images often used rough woodcuts, and the same images were used over and over. A printer might use the same woodcut for several different stories, which gave generic images with little detail (publishers used this same method once books became popular, repurposing plates for different editions).

The early printers were not concerned with fine art: the images caught the eye of the public and helped sell the chapbooks and broadsheets; they rarely advanced the story or were considered art.
In the early woodcuts, Little Red wears the hooded cape, a result of the 1729 translation of the "Red Riding Hood." By the 1830 s, images appear of the girl in a bonnet, sometimes with a cape. The German story is "Little Red Cap," and so she does not have the full riding cloak, while the Perrault translation can be seen as a fancy hat or "chaperon." It is the English illustrators who don the girl in her red hooded cape. Usually she wears an aproned dress-once color is introduced, her dress is almost always blue with a white apron (this may be due to lack of color options, or perhaps to the original Perrault image of a young woman in a blue gown).

In early depictions, the girl and the wolf are near trees, and there is often a house or a windmill in the background. This windmill comes from the Perrault version, as the girl tells the wolf that her grandmother lives near the mill. By the 1860s, the windmill disappears, and the woods tend to become darker and more menacing. This is perhaps a nod to the fact that more people are living in cities, moving away from nature and agrarian lifestyles to a more urban and mechanized lifeperhaps to symbolize the Victorian idea that nature was both grand and horrifying.

From the very beginning, the girl looks directly at the wolf. In the text, she is unafraid, presumably because she knows no better. By 1838, she can be seen looking at the wolf in what appears to be disdain; have the illustrators begun to give her more personality?

In an 1864 color illustration by Alfred Fredericks, ${ }^{7}$ the girl is shown looking down at the wolf in alarm. This is the earliest illustration I encountered that had the look of fine art-an illustration that gave the reader a bit more information and advanced the text.

By 1865, Gustave Doré depicts her as a girl with attitude-she is unafraid, but she does not appear to be a simpering child with no wits about her. In a famous illustration, the girl and the wolf are very close, nearly touching. The wolf looks down at her, and she looks up, as if to say, "I know you, I know who you are." It is at once sensual and slightly terrifying, as nature was in the poetry of the late Victorian times.

Doré's 1865 depiction of the girl and the wolf in bed is even more so, showing her pulling the covers up as if she has suddenly become modest, and she gives Granny Wolf a look with furrowed brow that says, "What is going on here?" While Doré was not the first to depict the girl and the wolf in bed like this, his illustration is recognized as fine art-one of the first uses of fine art in children's book illustration.

Published on the cusp of the 1870s when children's books began to be profitable items, it was often copied and imitated, perhaps signaling the idea that the girl can show emotion beyond that of a sweet little innocent child. 


\section{Analysis of Meeting the Wolf}

The Gaze: In the earliest versions examined, mainly rough woodcuts, the girl and the wolf are looking at one another. ${ }^{8}$ They face each other, or the girl looks over her shoulder at the wolf, or looks down as the wolf looks over or up at her. They are generally quite close to one another, and around the time that the Doré illustrations emerge, they move closer, often touching. The look on the girl's face is often coy or innocent-the text implies that she does not know any better, that she is unaware that the wolf is devious or dangerous. The illustrations very often show a look that has been described as seductive. This "gaze" appears as early as 1836 and is seen throughout the history of the illustrated tale. Though the depiction of the girl changes in dress style and age, you can count on her gazing into the eye of the wolf and him leering back at her.

Clothing: Clothing styles do change somewhat, reflecting the styles of the day, including red velvet capes with white fur in lavish Christmas editions for the Victorians and stylish capes in the 1920s. We see wooden shoes in the Grimm versions, and when the girl is shown as very young, her dress is shorter as befits a young child. Her hooded cloak is described most often as red, but on occasion it is crimson or scarlet, and it may be made of silk, velvet, or satin. Yet throughout the history of the tale, we recognize this girl in her red hooded cape, her blue aproned dress, and perhaps a red bonnet or cap.

It is interesting to note that "The Grandmother's Tale" includes no mention of red clothing; many scholars assume that Perrault added the color red to make her stand out, to dress her in aristocratic fashion. However, if one considers the 1022 manuscript, the girl is dressed in a red cloak in that story-perhaps the red was there all along.

Visually, we read these clues: a girl in deep woods, alone with a wild animal. Sharp angles in the teeth that show in the wolf's mouth indicate danger. The angles of trees and the dark, crowded woods increase the feeling of fear, as "dark" equals "scary" in visual terms. The wolf may be larger than the girl, which adds to the feeling of danger.

In Perrault versions, woodsmen are often seen working in the background, diminishing the sense of danger slightly, but building tension for the danger to come once the girl is completely alone with the wolf. Little changed in the composition of the meeting image other than the position of the wolf, the amount of space between girl and wolf, and the size of the wolf.

While the composition of the meeting stays relatively the same, the addition of color and the improvement of printing processes gave us better images. As we move into the $1860 \mathrm{~s}$ and through the 1890s, the girl gains a bit of attitude. We see emotion in her face-fear, astonishment, sassiness, doubt, concern. Her stance changes: she can be seen looking down or over, often in fear or bemusement. She may have her hand on her hip, as if to say "Really?" Her emotional range in the illustrations extends our understanding of the girl far beyond what the text tells us, as she is depicted in the text almost always as innocent and even silly or vapid.

The wolf is predictable-open mouth, teeth showing, often with the tongue out as though he is hungry. Walter Crane dresses the wolf and stands him as a man in 1875, and by the early 1900s, the clothed wolf is more common, and the wolf himself becomes a little more comical, as in William Wallace Denslow's depiction in $1903 .^{9}$

\section{What Big Eves You Have ...}

The first published image associated with the tale of the girl in the red bonnet comes via Perrault in 1695. ${ }^{10}$ The Baldwin collection owns a facsimile of a handwritten manuscript acquired in 1953 by the Pierpont Morgan Library in New York. ${ }^{11}$ In this image, there's a young woman (not a young girl), in bed, wearing a red hood or cap. She looks up at the wolf, who is in bed, atop her.

She is not afraid; in fact, she appears to caress the wolf's face. The bed is surrounded by a curtain, she is dressed in a blue robe, and her shoes are on the floor by the bed. These images will linger with the tale throughout history-the curtained bed, the blue dress, the loving-or at least unafraid-gaze into the wolf's eyes. This tiny gouache painting is 322 years old and has staying power.

This image is repeated in woodcuts found in the chapbooks of the 1800-1840 era. Into the later 1830s, the image becomes girl and Granny Wolf in bed together and is immortalized in Doré's image of 1862 (painting) and 1865 (engraving as published illustration). In this image is a slightly modest girl, pulling the blanket up as she looks at the wolf with shock, disdain, and perhaps a sudden realization of her error. These "in bed together" images appear in the Perrault versions or in the versions that are hybrids with heavy Perrault influence.

In the Grimm story, the girl does not get in bed with the wolf as she does in the Perrault tale; she approaches the bed and "comes closer" as Granny asks. The image in the Grimm or Grimm-heavy hybrids is the girl, next to the bed, often peering into a curtained bed, or looking closely at the wolf who is hidden under the blankets or quilt. She is often at the foot of the bed, holding her basket, or next to Granny Wolf.

By the 1870s, she shows shock and amazement at her Granny's long, furry arms or large nose. In the late 1860s to 1890s, a trend emerges that takes this image a bit further, showing the actual killing of the wolf by spear, pitchfork, knife, gun, etc. It was not uncommon to find images of a dead wolf on the floor, blood pooling around him. Seems the children of yore were not as tender as the children of today. 


\section{Conclusions}

It is somewhat surprising that the images have changed so little over the history of the story. The meeting image has changed more than the Granny Wolf image. There are two basic Granny Wolf images: the girl in bed with the wolf, and the girl next to the bed with Granny Wolf under blankets. A chair by the bedside; Granny Wolf in glasses, nightgown, and cap; shoes by the bed; and curtain around the bed are common to the depiction.

As we have seen, the meeting image has quite a few variations: The girl may be sitting or picking flowers; the woods may be deep and dark; the girl may be gazing at the wolf; the wolf may be large or more doglike; his mouth may be open and showing teeth. There may be woodsmen in the image; there may be a windmill in the background. There are more variables in the composition of the meeting image than in the Granny Wolf image.

Textually, the meeting is nearly always the same in the story: the girl is walking along a path in the woods and meets the wolf. She talks to the wolf. All versions have this element in common, but there is more variation in the imagery; perhaps the textual consistency allows the artist to elaborate and tell us more about the subtler details of the story. In the Granny Wolf image, the images are very consistent, and yet the story's resolution has many variants: Grandmother and Red are eaten and die; Grandmother and Red are eaten and then later cut out and saved; Grandmother is eaten and dies, while Red is saved and the wolf is killed; Grandmother is away on other business and Red is saved; Grandmother hides in a closet and Red is saved. These variations occur textually, and yet the image of Red and Granny Wolf is confined to one of two standard motifs.

Folklore scholars have written much on this story. Psychologists have analyzed it; feminists have lambasted it. Filmmakers have run wild with the story, and modern picture-book makers renew the story on a regular basis. Folktale specialist Jack Zipes has devoted a whole book to the story, its origins, its possible meanings, and its different versions. ${ }^{12}$

An Internet search will turn up countless articles and websites featuring this tale. It has become integral to the Western mind and has spread into Asia. As a children's story, the original tale may seem frightening. In fact, in an informal poll I conducted of nearly twenty youth librarians, all said they would not share the Grimm version with preschool children in a library setting, and yet parents have volunteered that "Little Red Riding Hood" is a favorite with their preschoolaged child.

Are we, as adults, afraid to share the tale for fear of frightening children? Do children understand that this is a warning story, and just that-a story? Can a story be just a story? Is it best to share a version that is updated with the mores of our current society? Whatever the answers may be, there are as many and more versions readily available of a tale that has been around for hundreds of years. \&.

In this article, I examine 158 individual books published between 1695 and 1939 (the 1695 example was a facsimile of a manuscript held in the Morgan Library and Museum). Among them were 2 books published before 1800, 83 published between 1800 and 1890, 73 published between 1890 and 1939, 71 published in the United Kingdom, 77 published in the United States, 2 published in France, and 8 by unknown publishers.

\section{References}

1. “Codex 196," 59v, CEEC: Codices Electronici Ecclesiae Coloniensis, University of Köln, Germany, accessed November 13, 2017, www.ceec.uni-koeln.de/ceec-cgi /kleioc/0010/exec/pagepro/\%22kn28\%2d0196\%5f118 .jpg\%22/segment/\%22body\%22.

2. Little Red Riding Hood (Chicago: Donohue and Co., 1906).

3. John L. Mitchell, "Big Bad Bottle of Wine Does in Red Riding Hood Schoolbook," Los Angeles Times, May 19, 1990, http://articles.latimes.com/1990-05-19/local /me-82_1_red-riding-hood.

4. James L. Matterer, “Sambocade Cheesecake," A Boke of Gode Cookery Recipes, 2000, www.godecookery.com/go derec/grec17.htm.

5. Catherine Ornstein, Little Red Riding Hood Uncloaked (New York: Basic Books, 2002), 26.

6. Sabine Baring-Gould, The Book of Werewolves (London: Smith, Elder, and Co, 1865), https://babel.hathitrust.org /cgi/pt?id=nyp.33433068179609;view=lup;seq=11.

7. R. Henry Stoddard, Little Red Riding Hood (New York: J. G. Gregory, 1864), 11.

8. Angela J. Reynolds, "The Better to See You With, Part 1: Exploring Little Red Riding Hood at the Baldwin Collection, University of Florida" (Bechtel Fellowship, 2017), accessed Nov. 13, 2017, www.slideshare.net/AngelaAVRL /the-better-to-see-you-with-part-1.

9. W. W. Denslow, W. W. Denslow's Little Red Riding Hood (New York: G. W. Gillingham Co., 1903).

10. Angela J. Reynolds, "The Better to See You With, Part 2: Exploring Little Red Riding Hood at the Baldwin Collection, University of Florida" (Bechtel Fellowship, 2017), accessed November 13, 2017, www.slideshare.net /AngelaAVRL/the-better-to-see-you-with-part-2.

11. Charles Perrault, Contes de la mère l'oye [Tales of Mother Goose] (New York: Pierpont Morgan Library, 1956).

12. Jack Zipes, The Trials and Tribulations of Little Red Riding Hood (New York: Routledge, 1993). 